\title{
Technique Effect on Carbon Emission Reduction through Internal and External channels: Evidence from China
}

\author{
Changqi Tao ${ }^{1, a}$ and Cui $\mathrm{Li}^{2, \mathrm{~b}}$ \\ ${ }^{1}$ School of Statistics, Jiangxi University of Finance \& Economics, China \\ ${ }^{2}$ School of Statistics, Jiangxi University of Finance \& Economics, China \\ atcq_822@sina.com, b1426934909@qq.com
}

\begin{abstract}
Keywords: technique effect carbon emission reduction internal and external channels Abstract: In this article, we conceptualize technique effect from a carbon emission reduction perspective, informed by the work of MacDougall, Shahbaz, and Daron Acemoglu and others following them. Building on this, we classify these determinants of technique effect into two typologies. Foreign trade and foreign direct investment are defined as external channel. Research and development are defined as internal channel. We set up a two-way fixed effect model to illustrate how technique advancement effect on carbon emissions reduction through different channels. Considering the regional heterogeneity, human capital is added in the model as interaction term. By using the panel data of 30 regions in China during the period from 2005 to 2012, regression results indicate that foreign direct investment and expenditure of R\&D significantly reduce carbon emissions in China, Technique effect of foreign trade on carbon emission reduction is not obvious. Techinque effect of foreign direct investment on carbon emission reduction has regional heterogeneity. Technique effect of FDI on carbon emission reduction also depends on the level of human capital. Wih the higher levels of human capital, the inhibitory effect of foreign direct investment on carbon emission is more significant.
\end{abstract}

\section{Introduction and Literature Review}

With the development of China's urbanization and industrialization, the consumption of coal, oil, natural gas and other energy have risen with enormous carbon dioxide emissions. The contradiction between economic growth and carbon emissions has been increasingly prominent. Low carbon economy had to be discussed on the agenda. Energy saving and emissions reduction need to be taken into account simultaneously. However, as is known to all, the capital shortage and the weak technological base in china are two difficulties in developing low-carbon economy. To solve this problem, china implements the positive reform and opening-up policy. Therefore, foreign direct investment and foreign trade can be regarded as the external channel through which to achieve technique effect on carbon emission reduction. MacDougall is the pioneer to analyze the technology spillover effect of foreign direct investment(MacDougall ,1960), Then the followers applied it to study its influence on carbon emission reduction. Many different theoretical perspectives are formed to investigate the impact of foreign direct investment on carbon emission reduction. They could be sum up to the following three points of views: foreign direct investment technology spillover help carbon reduction (Shahbaz,2011; Luo,2013) ;foreign direct investment technology spillover go against carbon emission reduction (Jorgenson et al,2007; Dai,2011);technique effect of foreign direct investment on carbon emission reduction is uncertain. Research has shown that impact of foreign direct investment on pollutants depends on the provincial human resource condition. The effect of foreign direct investment on carbon emission is quite other with different 
human capital in a given region.(Lan,2011; waise,2015).

There are also two opposite views on the relationship between trade and carbon emission. One point of view is that trade openness increases carbon emission. Alternative view is that the foreign trade reduces carbon emissions. International trade significantly promoted the technological progress in China, speeded up the introduction and absorption of foreign advanced technology and equipments, and improved the efficiency of energy utilization, so as to achieve the purpose of reducing carbon emissions (Cole,2004; Stan,2002; Sun,1998).

Technical research and development is the internal channel to reduce carbon emissions. Some scholars empirically analyzed the implication of $R \& D$ on the efficiency of carbon emissions by establishing models. Results show that R\&D not only promote the China's energy efficiency, but also effectively improve the ability of absorbing foreign R\&D technology. (Gao,2010; Mei,2010).

To sum up, the past studies of carbon emission reduction mostly focused on the perspective of separate technique effect. Comprehensive research on the internal-external channels of technique effect on carbon emission reduction is very few. We considered the regional heterogeneity in different channels. Human resource is described as an interaction term to represent this characteristic. In empirical analysis, we establish a two-way fixed effects model to estimate the influence of foreign trade, foreign direct investment and R\&D on the carbon emission reduction. Figure 1 shows the internal- external channels of technique effect on carbon emission reduction.

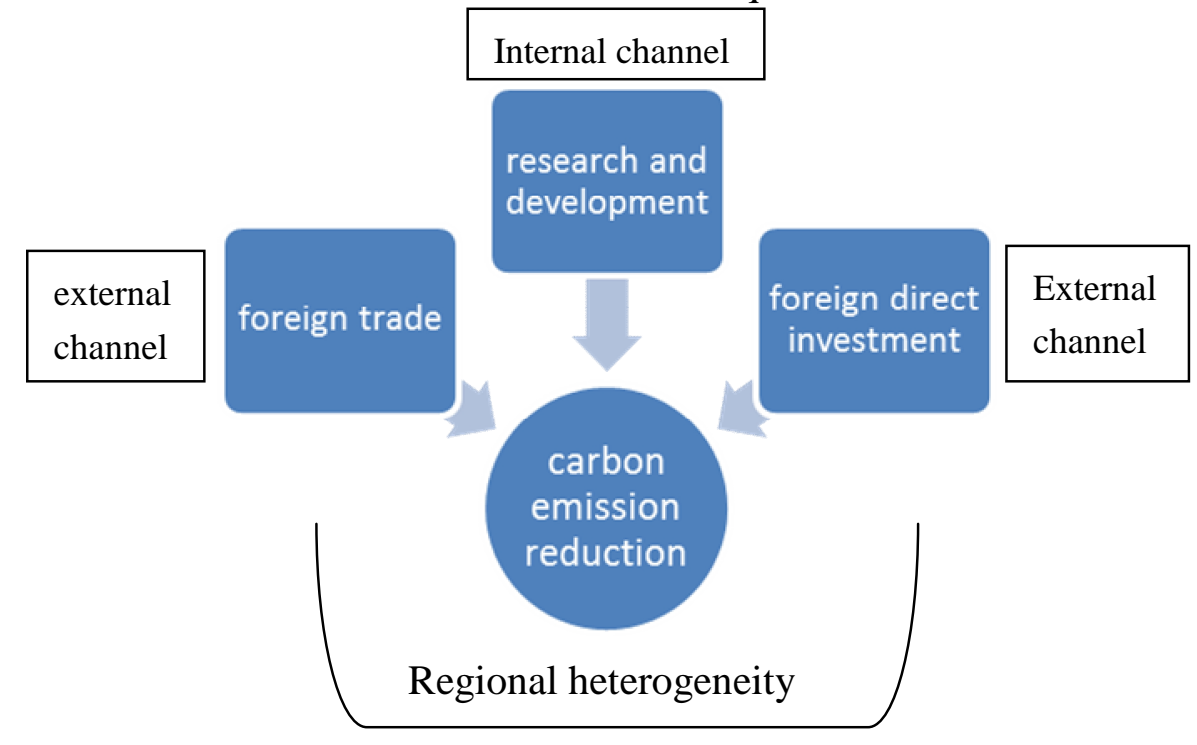

Fig.1 Internal-external channels of technique effect on carbon emission reduction

\section{Two-way fixed effect model of technique effect on carbon emission reduction}

Technical progress is useful for carbon emissions reduction. This technique effect can be divided into internal channel and external channel in an open economy. As R\&D expenditure grows ,the industrial technology is escalating. The quantity of input to every unit of product is declining, and so is the quantity of carbon emission. We defined this way to reducing carbon emissions as the internal channel. A country can also promote its technology by means of communication with other countries. Foreign trade and foreign direct investment can promote the skill level of the host country. We defined this way as the external channel of technique effect.

\section{Framework of the two-way fixed effect model}

In order to analyze comprehensive influence of technique effect on the carbon emissions through internal-external channels. Foreign trade、 Foreign development investment and R\&D expenditure are selected as core variables. Real GDP, industrial structure and energy intensity are chosen as control variables. 
A Two-way Fixed Effects model using 30 provincial or municipal data from 2005 to 2012 is built as follows:

$$
Y_{i, t}=\beta_{0}+\sum_{j=1}^{k} \beta_{j} X_{i, t}+\delta_{t}+\eta_{i}+\varepsilon_{i, t}
$$

$i$ is for individual, $t$ is for time, $Y_{i, t}$ is for $\ln _{-}$caremi $_{i, t}$, which is the logarithm of the carbon emissions, $Y_{i, t}$ is also for pecaremi ${ }_{i, t}$, which is the per capita carbon emissions ( logarithmic processing the data of carbon emissions to avoid heteroscedasticity ). $X_{i, t}$ is for the matrix of trade, FDI, R\&D, real GDP, energy intensity, and the ratio of secondary industry; $\beta_{0}$ is for constant, $\delta_{t}$ is for the intercept term; $\eta_{i}$ is for individual heterogeneity; $\varepsilon_{i, t}$ is for random perturbed variable.

\section{Data collection and processing}

According to the Carbon emissions calculation method provided by IPCC :

$$
\text { caremi }=\sum_{i}^{n} m_{i} \times \delta_{i}
$$

caremi is for carbon emission (Ten thousand tons of standard coal), i is for variety of energy sources. $m_{i}$ is for energy consumption , $\delta_{i}$ is for coefficient of carbon emission.

The value of the standard coal conversion coefficient of energy resources and carbon emissions coefficient is shown in table 1 basing on National greenhouse gas emissions listing guidelines published by IPCC. As carbon emissions coefficient changed little every year, and it is difficult to measure the carbon emission directly, we suppose the coefficient is fixed every year. The data of various energy consumption are from man-land system subject database and china economic information network.

Table 1 conversion coefficient and coefficient of carbon emissions

\begin{tabular}{ccc}
\hline Energy sources & Convert coefficient & Carbon emission coefficient \\
\hline original charcoal & 0.7143 & 0.7559 \\
coke & 0.9714 & 0.8850 \\
Crude oil & 1.4286 & 0.5857 \\
gasoline & 1.4714 & 0.5538 \\
Kerosene & 1.4714 & 0.5714 \\
diesel & 1.4571 & 0.5919 \\
Fuel oil & 1.4286 & 0.6185 \\
Liquefied petroleum gas & 1.7143 & 0.5042 \\
Liquefied natural gas & 1.7572 & 0.4483 \\
original charcoal & 0.7143 & 0.7559 \\
coke & 0.9714 & 0.8850 \\
\hline
\end{tabular}

Notes: $1 \mathrm{~kg}$ of liquefied natural gas $(\mathrm{LNG})=1.38$ cubic meters of natural gas; 1 cubic meters of natural gas $=0.7256 \mathrm{~kg}$ of liquefied natural gas $(\mathrm{LNG})$;

The trade indicator can be regarded as the ratio of total volume of foreign trade (IMEX) and GDP, which is also called foreign trade dependence degree. FDI indicator is shown as the ratio of real FDI 
and GDP measured by flow indicator as per Acharkyya's practice [17]. R\&D indicator is presented as the ratio of Domestic science-technology research and development expenses within budget and GDP. We make trade ,FDI and R\&D as core variable.

As the index of economic development, GDP values are deflated with price index in 2005 for the base period. The RGDP (real GDP) preferably describes the economic scale. Energy intensity is mean energy consumption per GDP, used for measurement of energy efficiency. Low energy intensity is equivalent of high energy efficiency. We choose the share of secondary industrial output to GDP as the proxy variable of industrial structure according to practice of Jorgenson $\backslash$ Perkins and Neumayer. Real GDP, energy intensity and industrial structure are regarded as control variables.

Considering the availability of data in China, the sample interval selected covers period 2005 -2012. All data come from China Yearbook, China's economic and social development statistical database,, science and technology of China website, provincial statistical information network, national data website. Due to the data incompleteness in Tibet, we only choose 30 provinces, autonomous regions and direct-controlled municipalities as sample objects. The missing individual data are made up by moving average method.

\section{Results}

\section{unit root test}

Since most macro data is not smooth, unit root test was carried out on the data first before regression analysis in order to avoid spurious regression. The method of unit root test is divided into two kinds:homogeneous unit root test and heterogeneous unit root test. The former refers to LLC test and Breitung test; The latter refers to IPS test, Fisher - ADF test and Fisher - PP test. Four methods are commonly used in the stationary test on the panel data. The test results are shown in table 2 .

Table 2 Panel unit root test results

\begin{tabular}{|c|c|c|c|c|}
\hline variable & LLC & IPS & Fisher-ADF & Fisher-PP \\
\hline lncaremi & $-2.98974 * * *$ & 2.40186 & 40.9456 & 98.0874 \\
\hline $\mathrm{d}($ Incaremi $)$ & $-9.48604 * * *$ & $-2.48169 * * *$ & $94.3822 * * *$ & $120.100 * * *$ \\
\hline pecaremi & $-33.0824 * * *$ & $-4.65968 * * *$ & $92.7377 * * *$. & $86.2370^{* * *}$ \\
\hline $\mathrm{d}($ pecaremi $)$ & $-7.82094 * * *$ & $-1.73571 * *$ & $79.9106^{* * *}$ & $111.782 * * *$ \\
\hline fdi & $-8.76203 * * *$ & $-1.41652^{*}$ & $85.6278 * *$ & $132.330 * * *$ \\
\hline $\mathrm{d}(\mathrm{fdi})$ & $-10.4651 * * *$ & $-2.67179 * * *$ & $89.6395 * * *$ & $120.101 * * *$ \\
\hline $\operatorname{tra}$ & $-4.03329 * * *$ & 0.30731 & 52.6538 & 55.4326 \\
\hline $\mathrm{d}(\mathrm{tra})$ & $-11.3478 * * *$ & $-3.30778 * * *$ & $103.092 * * *$ & $151.126^{* * *}$ \\
\hline $\mathrm{rd}$ & 0.90514 & 2.76096 & 46.1058 & 54.9805 \\
\hline $\mathrm{d}(\mathrm{rd})$ & $-15.0576 * * *$ & $-4.83376^{* * * *}$ & $126.766^{* * *}$ & $181.044 * * *$ \\
\hline lnrgdp & $-1.28599 *$ & 4.26128 & 54.8081 & $132.977 * * *$ \\
\hline d(lnrgdp) & $-8.43204 * * *$ & $-1.85484 * *$ & $78.7769 * *$ & $106.016^{* * *}$ \\
\hline eneint & $-9.06742 * * *$ & 1.50306 & 42.8096 & $95.9768 * * *$ \\
\hline $\mathrm{d}($ eneint $)$ & $-9.53238 * * *$ & $-2.52337 * * *$ & $97.9089 * * *$ & $109.707 * * *$ \\
\hline sec & -0.23505 & -0.22890 & $77.6440 *$ & 66.1381 \\
\hline $\mathrm{d}(\mathrm{sec})$ & $-16.1272 * * *$ & $-5.67458 * * *$ & $149.968 * * *$ & $199.893 * * *$ \\
\hline
\end{tabular}

$*$ at $10 \%$ 、**at $5 \%$ 、***at $1 \%$.t value of coefficient estimates.

As illustrated in table 2, data on some variables are not stationary with uint root. The test results of first difference on the panel data shows stationarity, indicating Variables in 1\%, $1 \%$ and $5 \%$ significance level significantly. They are integrated of order 1 , and co-integration test is available. 


\section{Panel data co-integration test}

In order to verify the long-term and stable relation, we analyze the long-term equilibrium relation among the variables by means of panel cointegration test. Padroni inspection results are shown in table 3:

Table 3 Panel cointegration test results

\begin{tabular}{ccc}
\hline & statistic & Prob. \\
\hline Panel & -2.040385 & 0.9793 \\
v-Statistic & 5.303986 & \\
Panel rho-Statistic & 1.001424 & 1.0000 \\
Panel PP-Statistic & -1.473019 & 0.8417 \\
Pane- & & 0.0704 \\
1ADF-Statistic & 8.326186 & 1.0000 \\
Group rho-Statistic & -4.122414 & 0.0000 \\
Group PP-Statistic & -3.467043 & 0.0003 \\
Grou- & & \\
pADF-Statistic & & \\
\hline
\end{tabular}

As is shown in the table 3, Panel v, Panel rho, and Panel PP are not approved by significance test, while Panel ADF-S-tatistic is approved by significance test of 10\%, Group PP-Statistic and Group ADF-Statistic are approved by significance test of $1 \%$.

Under Pedroni method, Group ADF statistic test effect works best compared with the other three kinds of statistics, especially in the small sample situation. The above variables are approved by significance test of Group PP and Group ADF, which means there is a cointegration relationship between variables, namely that carbon emissions has long term cointegrated relationship with various variables. Therefore model regression analysis can be performed.

\section{Estimation result and analysis}

A bidirectional fixed effects regression test was run by stata13 with carbon emissions logarithmic (ln caremi) as the dependent variable. As illustrated in the table4, the illustrated results show that the sample data fitting degree gets better gradually when join control variables one by one, and most estimation of the variables are in accordance with theoretical expectation. The variable coefficients change little indicating the robustness of measuring results. R\&D and FDI has significantly curb carbon emissions, while trade's impact on carbon emissions is not remarkable. Every one percent increase in R\&D leads to $15 \%$ augmentation in carbon emissions on the premise of other variables constant. So domestic R\&D input plays an important role to improve carbon emissions reduction. The more $R \& D$ input, the more skilled in $R \& D$, thus promoting technological progress, upgrading the industrial equipment, enhancing the management level and realizing energy conservation and emission reduction.

Table 4 Overall estimate model results

\begin{tabular}{lcccc}
\hline variable & In_caremi & In_caremi & In_caremi & In_caremi \\
& FE1 & FE2 & FE3 & FE4 \\
\hline fdi & -1.362 & $-1.975^{* *}$ & $-1.914^{* * *}$ & $-2.1706^{* * * *}$ \\
& $(-1.55)$ & $(-2.34)$ & $(-2.36)$ & $(-2.62)$ \\
tra & 5.051 & 10.28 & 12.22 & 3.7222 \\
& $(0.50)$ & $(1.08)$ & $(1.33)$ & $(0.39)$ \\
rd & $-18.28 * *$ & $-15.69^{* *}$ & $-12.55^{* * *}$ & $-15.5987 * * *$ \\
& $(-3.23)$ & $(-2.92)$ & $(-2.41)$. & $(-2.85)$ \\
lnrgdp & & $-0.950^{* * *}$ & $-0.832^{* * *}$ & $-0.783^{* * *}$ \\
& & & &
\end{tabular}




\begin{tabular}{|c|c|c|c|c|}
\hline \multirow{2}{*}{ eneint } & & $(-4.96)$ & $(-1.47)$ & $(0.76)$ \\
\hline & & & $\begin{array}{l}0.164^{*} \\
(4.20)\end{array}$ & $\begin{array}{c}0.7931 * \\
(4.07)\end{array}$ \\
\hline sec & & & & $\begin{array}{c}-0.0042 * * \\
(-3.14)\end{array}$ \\
\hline Constant & $\begin{array}{c}9.435 * * * \\
(0.109)\end{array}$ & $\begin{array}{c}16.62 * * * \\
(1.452)\end{array}$ & $\begin{array}{c}14.13 * * * \\
(1.515)\end{array}$ & $\begin{array}{c}13.07 * * * \\
(1.525)\end{array}$ \\
\hline Observations & 240 & 240 & 240 & 240 \\
\hline Number of id & 30 & 30 & 30 & 30 \\
\hline R-squared & 0.322 & 0.819 & 0.871 & 0.906 \\
\hline
\end{tabular}

$*$ at $10 \%$, **at $5 \%$, ****at $1 \%$.t value of coefficient estimates .

The conducting paths of technological effect have regional heterogeneity due to imbalance of regional economy development in china. Research regions are divided into three kinds such as eastern, central and western three areas, according to the economic development level. We add the interaction of FDI, trade, R\&D and human resources to the basic model, with the carbon emissions and per capita carbon emissions as the dependent variable. Model estimation results are shown in table 5 .

Table 5 Model Estimation and Results

\begin{tabular}{|c|c|c|c|c|c|c|}
\hline \multirow[t]{2}{*}{ variable } & \multicolumn{3}{|l|}{ ln_caremi } & \multicolumn{3}{|l|}{ pecaremi } \\
\hline & $\begin{array}{l}\text { eastern } \\
(1)\end{array}$ & $\begin{array}{c}\text { central } \\
(2)\end{array}$ & $\begin{array}{l}\text { western } \\
\text { (3) }\end{array}$ & $\begin{array}{l}\text { eastern } \\
(4)\end{array}$ & $\begin{array}{c}\text { central } \\
(5)\end{array}$ & $\begin{array}{l}\text { western } \\
(6)\end{array}$ \\
\hline fdi & $\begin{array}{l}-2.481 * * \\
(-2.4)\end{array}$ & $\begin{array}{l}-2.135 * * \\
(-2.44)\end{array}$ & $\begin{array}{l}-2.108 \\
(-1.55)\end{array}$ & $\begin{array}{l}-0.0491 * \\
(-0.1)\end{array}$ & $\begin{array}{l}-0.149 * \\
(-0.66)\end{array}$ & $\begin{array}{l}-0.490 \\
(-1.35)\end{array}$ \\
\hline tra & $\begin{array}{l}-14.96 \\
(-1.30)\end{array}$ & $\begin{array}{l}-24.12 \\
(-1.36)\end{array}$ & $\begin{array}{l}-23.69 \\
(-1.57)\end{array}$ & $\begin{array}{l}-9.886^{* *} \\
(-2.13)\end{array}$ & $\begin{array}{l}-2.142 \\
(-0.33)\end{array}$ & $\begin{array}{l}-2.216 \\
(-0.22)\end{array}$ \\
\hline $\mathrm{rd}$ & $\begin{array}{l}-3.605^{* * * *} \\
(-0.41)\end{array}$ & $\begin{array}{l}-3.567 * * \\
(-0.59)\end{array}$ & $\begin{array}{l}-2.618 * \\
(-0.38)\end{array}$ & $\begin{array}{l}-3.125^{* * * *} \\
(-0.88)\end{array}$ & $\begin{array}{l}-1.097 * \\
(-0.70)\end{array}$ & $\begin{array}{l}-4.563 * \\
(-1.79)\end{array}$ \\
\hline lnrgdp & $\begin{array}{l}-2.083 * * * \\
(-4.29)\end{array}$ & $\begin{array}{l}-1.301 * * * \\
(-7.65)\end{array}$ & $\begin{array}{l}0.179 * \\
(0.5)\end{array}$ & $\begin{array}{l}-1.327 * * * \\
(-6.79)\end{array}$ & $\begin{array}{l}-1.007 * * * \\
(-22.88)\end{array}$ & $\begin{array}{l}0.673 * * * \\
(8.63)\end{array}$ \\
\hline eneint & $\begin{array}{l}2.600 * * * \\
(8.82)\end{array}$ & $\begin{array}{l}0.0169 * \\
(0.65)\end{array}$ & $\begin{array}{l}0.592 \\
(6.36)\end{array}$ & $\begin{array}{l}0.185^{*} \\
(1.56)\end{array}$ & $\begin{array}{l}0.000336 * \\
(0.05)\end{array}$ & $\begin{array}{l}0.117 \\
(5.80)\end{array}$ \\
\hline $\sec$ & $\begin{array}{l}0.00103 * * \\
(0.82)\end{array}$ & $\begin{array}{l}0.00145^{*} \\
(0.16)\end{array}$ & $\begin{array}{l}0.0135 \\
(0.54)\end{array}$ & $\begin{array}{l}0.00233 * * * \\
(4.62)\end{array}$ & $\begin{array}{l}0.00174 * \\
(0.74)\end{array}$ & $\begin{array}{l}0.00450 \\
(0.83)\end{array}$ \\
\hline $\mathrm{h}^{*} \mathrm{fdi}$ & $\begin{array}{l}0.234 * * * \\
(0.25)\end{array}$ & $\begin{array}{l}1.386^{*} \\
(1.20)\end{array}$ & $\begin{array}{l}-0.497 \\
(-0.21)\end{array}$ & $\begin{array}{l}0.492 * * \\
(1.74)\end{array}$ & $\begin{array}{l}0.537 * * \\
(1.97)\end{array}$ & $\begin{array}{l}0.309 * \\
(0.62)\end{array}$ \\
\hline$h^{*} \operatorname{tra}$ & $\begin{array}{l}-7.485 \\
(-1.52)\end{array}$ & $\begin{array}{l}117.7 * * * \\
(3.44)\end{array}$ & $\begin{array}{l}-47.01 \\
(-0.83)\end{array}$ & $\begin{array}{l}2.019 \\
(1.36)\end{array}$ & $\begin{array}{l}41.66^{* * * *} \\
(5.13)\end{array}$ & $\begin{array}{l}-23.65^{*} \\
(-2.01)\end{array}$ \\
\hline h*rd & $\begin{array}{l}1.067 \\
(0.68)\end{array}$ & $\begin{array}{l}0.536 \\
(0.10)\end{array}$ & $\begin{array}{l}5.666 \\
(1.05)\end{array}$ & $\begin{array}{l}3.461 * * * \\
(7.29)\end{array}$ & $\begin{array}{l}1.570 \\
(1.22)\end{array}$ & $\begin{array}{l}0.571 \\
(0.51)\end{array}$ \\
\hline Constant & $\begin{array}{l}-32.57 * * * \\
(-5.11)\end{array}$ & $\begin{array}{l}19.27 * * * \\
(13.54)\end{array}$ & $\begin{array}{l}4.621 \\
(1.61)\end{array}$ & $\begin{array}{l}-9.730 * * * \\
(-4.69)\end{array}$ & $\begin{array}{l}-8.138 * * * \\
(-25.61)\end{array}$ & $\begin{array}{l}-5.650 * * * \\
(-5.62)\end{array}$ \\
\hline Observations & 96 & 80 & 64 & 96 & 80 & 64 \\
\hline Number of id & 12 & 10 & 8 & 12 & 10 & 8 \\
\hline R-squared & 0.903 & 0.949 & 0.951 & 0.996 & 0.999 & 0.999 \\
\hline
\end{tabular}

* 、**,*** present $10 \%, 5 \%$ and $1 \%$ significance level;

As is shown in table 5, inhibitory effect of FDI on carbon emissions is remarkable. The reduction 
effect of increasing FDI on carbon emissions appeared gradually weakening trend from east to west. There is a negative correlation between foreign trade and regional carbon emissions, with significant effect of trade on per carbon emissions in eastern area compared to others. $R \& D$ in various areas has a significant negative relationship with carbon emissions, depending on regional economic development level. This suggests that the technical effects caused by internal channels plays an active role in energy conservation and emissions reduction. Technology innovation enhances the energy saving technique, and improves the high energy consuming equipment, thus reduces carbon dioxide emissions. Real GDP per capita effect significantly, energy intensity reduction. Industrial restructuring are both in favor of carbon emissions reduction.

By comparing the interaction of FDI, trade, R\&D and human capital, we find that only the interaction item of human capital and FDI is significantly positive, indicating that FDI effect on carbon emissions are affected by human capital. FDI effect on the environment pollution depends on the human capital level. When the human capital level is high, It appears a negative relationship between FDI and pollutant emission, and otherwise when the level of human capital is low. It means only when high levels of human capital of certain region, FDI promote local technology absorption, and make positive contribution on pollutant emission. As can be seen in table 5, the influence of FDI on carbon emissions appears difference under different human capital level. The eastern part of the human capital level is significantly higher than the central and western regions. So FDI effectively reduce the carbon emissions and promote the development of low carbon economy by means of enhancing human capital level.

\section{Conclusions}

This paper extends the existing empirical analyses of various technique effect on carbon emissions reduction by decomposing technology progress into two channels of external channel containing trade as well as FDI and internal channel referring to science and technology R\&D at a detailed regional level for 30 china's provinces or municipalities, covering the period 2005-2012. Fixed effect parameter estimation revealed that FDI and R\&D significantly reduced carbon emissions in China, R\&D effect on carbon emissions and carbon intensity is more evident than FDI. The external channel embodying FDI and R\&D is an important channel for technology effect of carbon emissions reduction. Trade effect on carbon emissions reduction is not obvious, but trade helps to achieve energy conservation and emissions reduction in china. Fixed effect parameter estimation, adding the interaction of human capital and FDI, trade, and R\&D, led to the conclusion that FDI effect on carbon emission reduction exists regional heterogeneity. The inhibitory effect of FDI on carbon emissions depends on the regional human capital level.

\section{Acknowledgements}

This work was sponsored by the China National Nature Science Foundation (71273122, 71473109, $71463023,41461025)$. The authors are grateful for the anonymous reviewers who made constructive comments.

\section{References}

[1]Anderw K Jorgenson.Does Foreign Investment Harm the Air We Breathe and the Water We Drink [J]. Organization Environment,2007,(20):137-156.

[2]Cole , M.A. and Elliott , R.J.R. Determining the Trade-Environment Composition Effect :the Role of Capital, Labor and Environmental Regulations [ J], Journal of Environmental 
Economics and Management ,2003, 46 (3), 363-383.

[3]Cole , M.A.Trade. The Pollution Haven Hypothesis and the Environmental Kuzne 
Curve:Examing the linkage [ J] , Ecological Economics, 2004,48 (1), 71-81.

[4]IPCC/UNEP/OECD/IEA.Revised 1996 IPCC guidelines for National Greenhouse Gas Invento ries[R].Paris: Intergovernmental Panel on Climate Change, United Nations Environment Program, Organization for Economic Co-Operation and Development, International Energy Agency,1997.

[5]IPCC/IGES.2006 IPCC Guidelines for National Greenhouse Gas Inventories[R].Geneva: Inter governmental Panel on Climate Change, Institute for Global Environmental Strategies,2006.

[6]Joysrl Acharkyya.FDI,growth and the environment: evidence from India on CO2 emission during the last two decades [J]. Journal of Economic Development,2009(6) : 43-58.

[7]Lan J,Kakinaka M,Huang X. Foreign Direct Investment, Human Capital and Environmental Pollution in China [J]. Environment Resource Economy, 2011(51):55-75.

[8]Matthew A Cole, Robert Elliott and Shanshan Wu.Industrial activity and the environment in China: an industry - level analysis [J]. China Economic Review,2008(19) : 393-408.

[9]Perkins and Neumayer:Transnational linkages and the spillover of environment-efficiency into developing countries[J]. Global Environmental Change,2009(19) : 375-383.

[10]Perkins R,Neumayer E. Transnational linkages and the spillover of environment efficiency into developing countries [J]. Global Environmental Change, 2009, 19 (5): 375-383.

[11]Shahbaz M,Nasreen S,Afza T. Environmental Consequences of Economic Growth and Foreign Direct Investment:Evidence from Panel Data Analysis [R]. Munich: MPRA Paper No.32547, 2011.

[12]Luo Liangwen, Li Shanshan. FDI international trade's technical effect and provincial carbon emissions in china $[J]$. International Trade,2013(8):142-150

[13] V.Thavasi,S.Ramakrishna.Asia energy mixes from socio-economic and environmental perspectives[J].Energy Policy37(2009)4240-4250

[14]Hsiao-Fan Wang,Meng-Ping Sung,Hsin-Wei Hsu.Complementarity and substitution of renewable energy in target year energy supply-mix plannin-in the case of Taiwan[J].Energy Policy 90(2016)172-182

[15]Erik Gawel,Sebastian Strunz,Paul Lehmann.A public choice view on the climate and energy policy mix in the EU-How do the emissions trading scheme and support for renewable energies interact? [J].Energy Policy 64(2014)175-182

[16]Tyler J.Vanderweele.Empirical and counterfactual conditions for sufficient cause interactions [J].Biometrika(2008),95,1,pp,49-61

[17]Joseph S.Shapiro and Reed Walker. Why is Pollution from U.S. Manufacturing Declining? The Roles of Trades, Regulation,Productivity and Preferences.[J].NBER Working Paper No.20879. January 2015,Revised September 2015. JEL No.F18,F64,H23,Q56

[18]Andreas Jess. What might be the energy demand and energy mix to reconcile the world's pursuit of welfare and happiness with the necessity to preserve the integrity of the biosphere? [J].Energy Policy38(2010)4663-4678

[19]Fateh Belaïd.Understanding the spectrum of domestic energy consumption:Empirical evidence from France[J].Energy Policy92(2016)220-233

[20]Daron Acemoglu,Philippe Aghion,Leonardo Bursztyn, and David Hemous.The environment and Directed Technical Change[J].American Economic Review2012,102(1):131-166

[21]Rosie Day,Gordon Walker,Neil Simcock.Conceptualising energy use and energy poverty using a capabilities framework[J].Energy Policy93(2016)255-264 